\title{
The Implementation of Swimming Games Learning for Pre-School Students in Singapore Piaget Academy
}

\author{
Afina Zakiah Kusumaningrum; Agus Kristiyanto; Slamet Riyadi \\ Program Studi Ilmu Keolahragaan, Sebelas Maret University of Surakarta, Indonesia
}

http://dx.doi.org/10.18415/ijmmu.v6i4.967

\begin{abstract}
The game is one of the effective approaches in implementing swimming learning activities in children. The purpose of this research is to find out the most popular swimming game learning students and increase the courage to learn to swim. This research is a survey research with a quantitative approach. The sample of this study was 12 female students with age criteria 5-6 years with purposive sampling technique. Data analysis was performed using descriptive statistics. The results showed that providing a variety of swimming aids equipment that is attractive to children will provide an interest in playing, and the courage of children to play with water. It also will provide benefits when playing while learning with swimming, thus providing the basic ability of swimming for children to make movements such as gliding, moving with legs, jumping and others.
\end{abstract}

Keywords: Learning; Games; Swimming

\section{Introduction}

Swimming games learning for pre-school is also called aquatic activity. Swimming game learning can also be interpreted as moving forward in water by using aids or not using tools. The movements that are carried out can sometimes resemble a person riding a bicycle, moving and floating bodies, from one place to another. Swimming game learning is done by using a timeline or not, there are many developments in swimming movements that have been planned, and various types of swimming styles in a race (Wilhelm, 1997: 13).

Aquatic is an activity in the water with the aim of training children to advance their motor, cognitive, affection and social potential. According to Susanto (2014: 23), aquatic is all kinds of water activities that can be carried out in rivers, lakes, seas, beaches and swimming pools. One of the activities used to advance motor, cognitive, affective and social potential is swimming. Bompa (1990: 35), states that learning to swim should ideally begin at the age of 3-7 years. At the age of 10-12 years, the age for specialization, while the age of peak achievement ranges from the age of 16-18 years. Students taken in this study are children aged 5-6 years in the Kindergarden 2 (K2) ELC Program Singapore Piaget Academy Grogol Solo Baru. 
As the initial observation, swimming activities in ELC learning schools are conducted 1 (one) school year, per 3 months held once per week meeting. The schedule is randomized with other sports and every Friday an extracurricular is held. Swimming game learning is carried out for 1 hour which is 60 minutes, and efficient learning time is used only 30 minutes, the other 30 minutes is used for bathing. Based on interviews with sports teachers, a 30 minute learning activity is enough for ELC children, because swimming learning has a purpose only for pleasure.

Infrastructure facilities at the school, still need a lot of handling. Swimming aids equipment has not been used optimally so that students' interests are less interested in aquatic learning. The implementation of learning is still less structured. The game-based aquatic learning model using a combination of swimming aids equipment has not been able to attract students' preferences in the process of aquatic learning. Aquatic learning seems to be slow and has not yet reached the desired target. Children are still afraid of water, shyness and insecurity arise, a sense of lack of interest and other feelings.

Aquatic learning research with swimming aids equipment combination models, still rarely research comprehensively. This needs to be research into game-based aquatic learning so as to know the tendencies or desires and preferences of students in the use or combination process of using swimmming aids equipment.

According to Hendrayana (2007: 43) aquatic learning utilizes environment, skills, facilities, tools, and modified learning strategies. Adaptive aquatic comprises all types of activities in water. Meanwhile, according to Setiawan (2008: 3) aquatic activity or physical activity in shallow water is a sport that is carried out in shallow water, children before entering the swimming pool must wear swimsuits. Aquatic activities include warming up, entering a swimming pool, walking in a pool and playing in shallow water such as splashing water on a friend, diving and floating, chasing a friend, carrying a friend, leg training with a buoy, chasing a ball in the pool. Aquatic activities carried out in swimming pools are known as swimming activities, beautiful jumping, water polo (Susanto, 2005: 118).

Swimming aids equipment is a learning media in aquatic learning. The use of media and learning resources in the implementation of learning is important to be mastered by a teacher. According to Rusman (2013: 77) media is everything that can be used to channel messages (learning material), stimulates the mind, everything that can be used to distribute messages (learning material) so that it can encourage the learning process.

The choice of toys brought to the pool is not limited by the teacher's imagination but rather that children will naturally be interested in exploring the aquatic environment through play. The use of toys and colorful equipment in this study is called Swimming aids equipment. Swimming aids equiptment is very helpful for teachers in developing learning themes and making learning programs more interesting for children.

\section{Research Methods}

This study uses a survey method, with a quantitative approach. Sugiyono (2016: 13) states that quantitative methods are research methods based on the philosophy of positivism, used to examine specific populations or samples, Sampling techniques are generally carried out randomly, collecting data using research instruments, quantitative or statistical data analysis with the aim to test the hypotheses that have been set. Swimming game learning is done by referring to a program of activities that have been arranged, so as to be able to stimulate the behavior and basic abilities of children to be developed as well as possible (Spengler, 2001; Clement, 1997). The game is one of the effective approaches in carrying out learning activities in children. 
The population in this study were all Kindergarden Singapore Piaget Academy students. The sample of this study was 12 female students with age criteria 5-6 years with a purposive sampling technique.

Data analysis was performed using descriptive statistics. The result is a picture of children's interest in playing water with various swimming aids equipment.

\section{Results And Discussion}

Observations were made on 12 female students of the ELC Kindergarden 2 Program while doing aquatic activities that are scheduled in class twice a week on Tuesdays and Fridays After data collection, the data is obtained as shown in Table 1.

Table 1. Children's Interest

\begin{tabular}{ccc}
\hline & \multicolumn{2}{c}{ Children's Interest } \\
\cline { 2 - 3 } & Interested & Not interested \\
\hline Total & 10 & 2 \\
\hline Percentage & $81 \%$ & $19 \%$ \\
\hline
\end{tabular}

Based on the results of data collection as shown in table 1 above it is known that of 12 children, $71 \%$ were interested and 29\% were not interested. The graph can be seen in Figure 1.

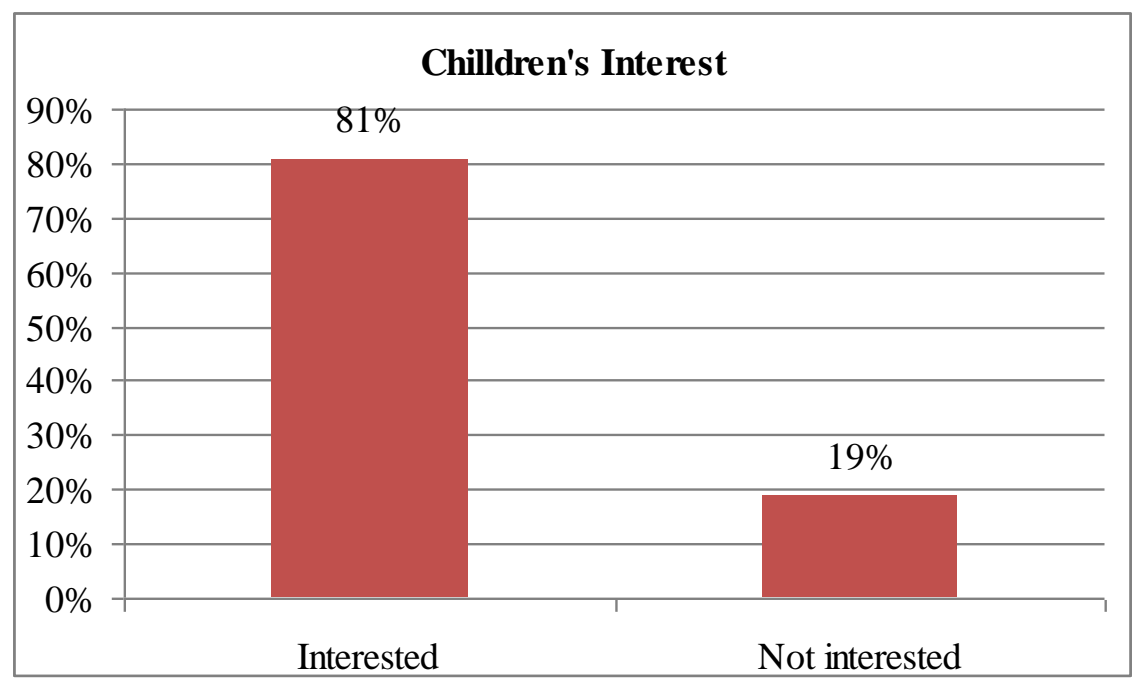

Figure 1. Percentage of Student Interest

The results of student's courages are presented in table 2.

Table 2. Student's Courages

\begin{tabular}{lcc}
\hline & \multicolumn{2}{c}{ Courages } \\
\cline { 2 - 3 } & Dare & Not Dare \\
\hline Total & 11 & 1 \\
\hline Percentage & $88,0 \%$ & $12 \%$ \\
\hline
\end{tabular}


Based on the results of data collection as shown in table 2 above it is known that of 12 children, $88 \%$ are brave and $12 \%$ are not brave. Graphically it can be seen in Figure 2.

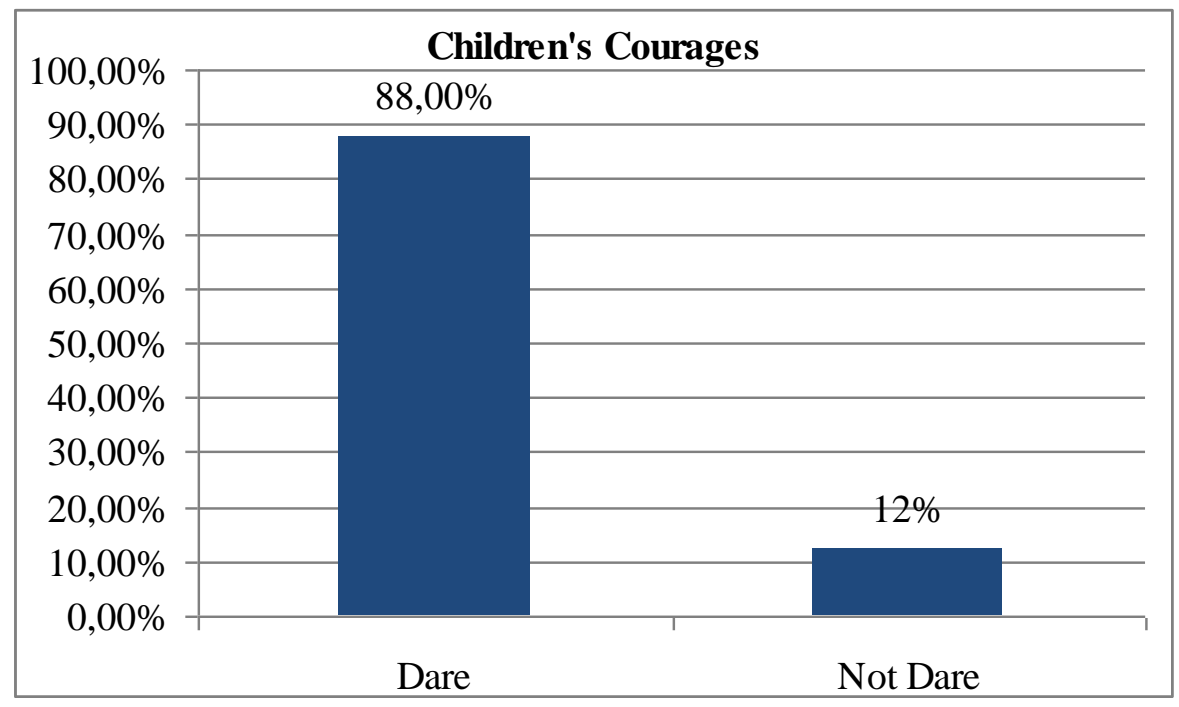

Figure 2. Percentage of Student Courages

Students already have an interest and courage in learning swimming games. On the results the basic abilities of students are shown in table 3 .

Table 3. Student's Basic Skills

\begin{tabular}{lcc}
\hline & \multicolumn{2}{c}{ Basic Skills } \\
& There is an increase & There is no increase \\
\hline Total & 9 & 3 \\
Percentage & $76 \%$ & $24 \%$ \\
\hline
\end{tabular}

Based on the results of data collection as shown in table 3, it is known that of 12 children, $76 \%$ had an increase and $24 \%$ had no increase. Graphically it can be seen in Figure 3.

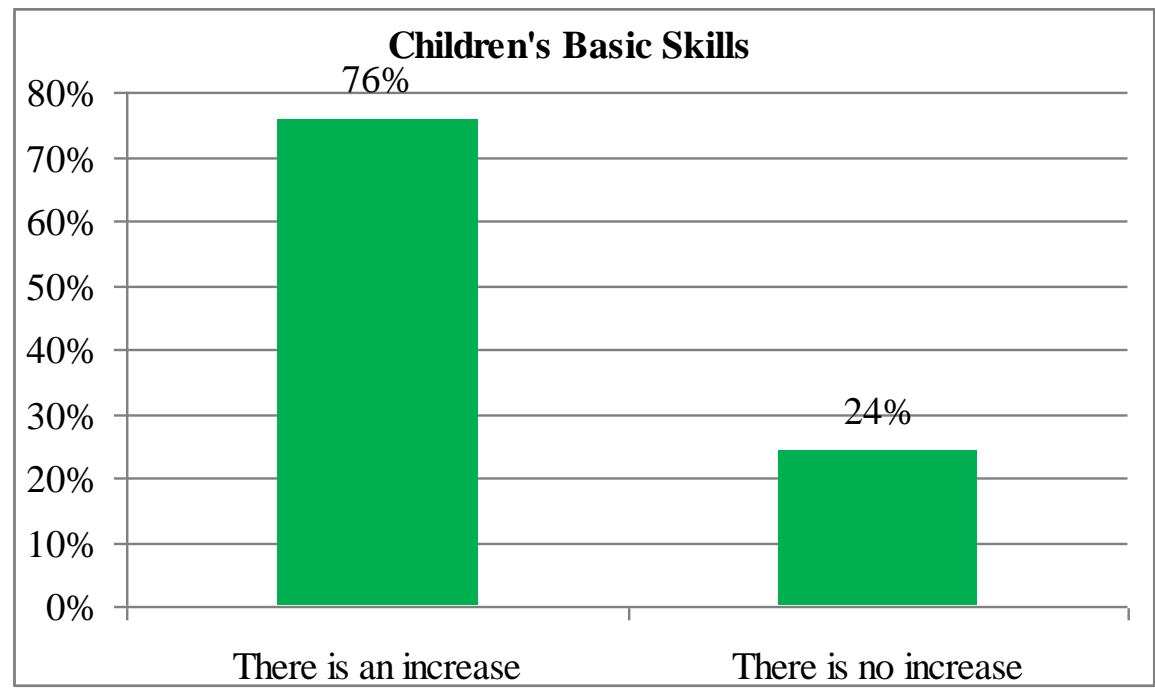

Figure 3. Percentage of Basic Skills 
This shows that with a wide variety of swimming aids equipment that appeals to children both in form and function can give children the interest to want to play with water. This will also give a score of courage to children in their subsequent activities such as not being afraid of water, wanting to pick up toy objects in water (swimming toys), being brave without using a float but still using water glasses and others. It also will provide basic skills, if the child dares to play water to have basic abilities such as swimming, sliding forward, jumping in water and others. It also proves that swimming aids equipment is very helpful for teachers in developing learning themes and making learning programs more attractive to children.

\section{Conclusion}

Based on the results of the study it can be concluded that by providing a variety of swimming aids equipment that is interesting for children, will provide an interest in playing, and the courage of children to play with water. It also will provide benefits when playing while learning with swimming, thus providing the basic ability of swimming for children to make movements such as gliding, moving with legs, jumping and others.

\section{References}

Clement, A. 1997. Legal Responsibility in Aquatics. Aurora. OH: Sport and Law.

Hendrayana, Y. 2007. Pendidikan Jasmani dan Olahraga Adaptif (Adapted Phycical Education and Sport). Jepang: CRICED (University of Tsukuba).

Rusman. 2013. Model-Model Pembelajaran. Jakarta: Raja Grafindo Persada.

Setiawan, A. 2008. Olahraga Renang. Bandung: CV. Acarya Media Utama.

Spengler, J.O. 2001. Planning for Emergencies in Aquatics. Journal of Physical Education, Recreation \& Dance; Mar 2001; 72, 3; ProQuest Education Journals pg. 12.

Sugiyono.2016.Metodologi Penelitian Pendidikan Pendekatan Kuantitatif, Kualitatif, dan R\&D. Bandung: Alfa Beta.

Susanto, E.2005.Strategi Menghilangkan Fobia Air: Sebuah Pendekatan Menuju Keamanan Pembelajaran Aquatik. Jurnal Pendidikan Jasmani Indonesia, Edisi Khusus, 2005. (p. 1-8).

Susanto, E. 2014. Pembelajaran Akuatik Berbasis Permainan. Yogyakarta: UNY Press.

Wilhelm, M. 1997. Renang Membahas Teknik, Sarana \& Fasilitas. Semarang: Dahara Prize Semarang.

\section{Copyrights}

Copyright for this article is retained by the author(s), with first publication rights granted to the journal. This is an open-access article distributed under the terms and conditions of the Creative Commons Attribution license (http://creativecommons.org/licenses/by/4.0/). 